\title{
WHAT WE HAVE LOST FROM WHAT HAVE BEEN DONE: ETHICAL PROBLEMS OF THE SALVAGED SHIPWRECK CARGOES IN INDONESIA
}

\section{APA YANG TELAH HILANG DARI YANG SUDAH TERJADI: ISU- ISU ETIKA PENGANGKATAN KAPAL KARAM DI INDONESIA}

\author{
Hutomo Putra \\ Badan Keamanan Laut Republik Indonesia \\ hutomohardjoko@gmail.com
}

\begin{abstract}
ABSTRAK
Pergolakan isu-isu etika mengenai situs dan tinggalan budaya bawah air telah terjadi di Indonesia selama dua dekade terakhir. Selama itu, perusahaan komersial bekerjasama dengan Panitia Nasional telah menemukan dan mengangkat kargo bawah air dalam jumlah yang banyak. Sayangnya, sebagian besar kegiatan ini terjadi tanpa keterlibatan arkeolog dan kurang memperhatikan kaidah arkeologis. Semenjak 2010 Pemerintah Indonesia telah menerbitkan moratorium, menghentikan sementara aktivitas survei dan pengangkatan, serta melarang jual-beli artefak terkait. Kini, lebih dari 190,000 artefak yang telah diangkat disimpan di gudang Komite Kapal Tenggelam Nasional di Cileungsi. Penelitian ini menggambarkan kerugian yang ditimbulkan oleh kegiatan pengangkatan komersial, dan pelelangan artefak tersebut. Penelitian ini juga mendiskusikan beberapa rekomendasi mengenai sistem etika perlindungan dan manajemen jangka panjang sumberdaya budaya maritim Indonesia, termasuk artefak yang kini sedang disimpan di gudang Komite Kapal Tenggelam Nasional.
\end{abstract}

Kata Kunci: Pengangkatan kapal karam; Komite Kapal Tenggelam Nasional; sumberdaya budaya bawah air

\begin{abstract}
ABSTRAK
The struggle in the ethical issues of submerged underwater sites and underwater cultural heritage have been undertaking in Indonesia for the last two decades. During these years, commercial companies in collaboration with the National Shipwreck Committee (NSC) recovered and salvaged substantial numbers of material cargoes. Unfortunately, the majority of these operations occurred without the involvement of archaeologists and lack of proper and controlled archaeological methods. Since 2010, the Indonesian Government has declared a moratorium that temporarily stopped all commercial survey and salvage activities, and prohibits the sale of the artefacts. Nowadays, more than 190,000 artefacts are currently stored at the National Shipwreck Committee warehouses in Cileungsi. This study attempts to illustrate the disadvantages of the commercial salvage practices and the auction of salvaged artefacts. This research also discusses recommendations to a more ethical system of protection and the long-term management of the Indonesian maritime cultural resources, including its existing collections from salvaged shipwreck sites that are stored at the NSC warehouse today.
\end{abstract}

Keywords: Salvaged material cargoes; National Shipwreck Committee; underwater cultural heritage

$\begin{array}{ll}\text { Artikel Masuk } & : 29-07-2019 \\ \text { Artikel Diterima } & : 11-10-2019\end{array}$




\section{INTRODUCTION}

As a country with a rich history and significant maritime cultural resources, Indonesia has experienced a true struggle with the ethical issues related to submerged archaeological sites and underwater cultural heritage. In fact, Indonesia is a country with a long track-record of commercial salvage and illegal looting, a lack of human resources to protect and research archaeology resources, inadequately trained underwater cultural heritage professionals, and issues related to the ethical considerations of the management of underwater cultural heritage (Flecker, 2012, pp. 12-15). All the aforementioned factors and issues are problematic from an Indonesian Government perspective.

The commercial salvage activities are not unique to Indonesia but are a major ethical issue for underwater archaeology projects around the world (Bass, 2011, pp. 11-14). Maritime or underwater archaeology aims to collect artefactual information and study the context of material cultures, while the main purpose of salvaging activity is the collection of material cultures for trading activity based on their monetary values (Bass, 1966, pp. 16-17; 2011, pp. 11-14). Furthermore, the international best-practice standard for archaeology or underwater cultural heritage management is to keep datasets or collections together and, thus, maintain knowledge from these shipwreck sites and make them available for public access and future study. Salvage operations on the other hand calculate the most profit that can be made from minimum effort and hardly ever considers long-term preservation options (Maarleveld, 2011, pp. 930-934).

Related issues of the management of underwater cultural heritage are comprised of many aspects. The problems with substandard underwater cultural heritage legislation and its impact on archaeological resources are considered as one of the related issues in this research. Most problematic, Indonesia has two contradictive legislations pertaining to underwater cultural heritage that are administered within two different Indonesian Government institutions. The Coastal Zone and Small Islands Department, the National Shipwreck Committee Unit of the Ministry of Marine and Fishery administers the Salvage and Utilization of the Valuable Material Cargoes from the Sunken Ship legislation, while the Cultural Heritage Protection Division of the Ministry of Education and Culture is the Government's delegate for the Cultural Heritage Protection Act. It shows that Cultural Resources Management (CRM) in Indonesia includes and allows for the involvement of commercial and political interests in underwater cultural heritage and thus facilitates treasure hunting (Lenihan, 1982, pp. 42).

The Salvage and Utilization of the Valuable Material Cargoes from the Sunken Ship legislation was drafted and endorsed by the National Shipwreck Committee in 1990. The formation of this committee and the 1990 legislative measures were the Indonesian Government's response to the first well-known salvage case in Indonesia: that of the Geldermalsen shipwreck by Michael Hatcher. The Geldermalsen site on Heluputan Reef represented the remains of a Dutch East India Company ship that sank in 1752 (Edwards, 2000; Johnston, 1997, pp. 287-288). The salvaged, archaeological artefacts from this 18th-century shipwreck, such its cargo of ceramics were auctioned via Christie's Auction House and raised \$20 million (Christie, 1986), triggered a porcelain boom in the global art market (Sheaf \& Kilburn, 1988; Jörg, 1986). 
Since the legislative framework came into being, commercial surveys and salvage operations continued from 1990 to 2010 and were undertaken in Indonesian waters by salvage companies in collaboration with the National Shipwreck Committee. During these 20 years, commercial companies recovered and salvaged substantial numbers of material cargoes. The majority of these operations occurred without the involvement of archaeologists and lack of proper and controlled archaeological methods and excavation techniques. Since 2012, the Indonesian Government has declared a moratorium that temporarily stopped all commercial survey and salvage activities, and prohibits the sale of the artefacts. As a result, more than 190,000 artefacts raised by salvagers are currently stored at the National Shipwreck Committee warehouses near Jakarta, in Cileungsi, West Java, Indonesia. All artefacts in this storage are not conserved and have yet to undergone conservation treatment-all artefacts raised prior to 2010 still await proper ex-situ recording, conservation treatment, study, and collection management.

The aforementioned issues all relate to the commercial or economic perspectives of the salvage of shipwrecks and their valuable material cargoes. In fact, the Indonesian Government's position has been to make a profit from the selling of material cargoes from shipwreck sites rather than their optimization, utilization, and preservation for the benefits of further research, public knowledge and programs, and benefitting from the site and their associated artefacts as the cultural heritage tourism precincts. The latter considers shipwreck sites as long-term benefactors of Indonesian society, cultural heritage and the local economy. Since the formation of the National Shipwreck Committee, the Indonesian Government has mainly aimed to oversee shipwreck exploration and establish regulations designed to provide benefits for private treasure hunting companies from the sale of recovered material cargoes (Adams, 2010, hlm. 68). Such companies need to meet specific requirements to work including: the use of an Indonesian-registered company; the payment of a deposit and fees: acquiring permission from up to 22 different government departments: while maintaining minimum archaeological standards and submitting to on-site supervision by Indonesian authorities (Flecker, 2002, pp. 20-22).

As a result of the 2012 moratorium on commercial survey and salvage activities, commercial salvage operations have been temporarily put on hold and projects already in progress were stopped-they remain unfinished to date. Furthermore, all sales or auctions of salvaged archaeological materials have been prohibited for the duration of the moratorium. The moratorium has effectively created a loss of funds already invested by commercial companies into the salvage operations of shipwreck sites. Plus, as aforementioned, cultural material rose by commercial salvage companies are now stored in the National Shipwreck Committee warehouse and remain untouched.

The question arises: why does Indonesia still focus on commercial salvage operations and allows for the sale of its cultural heritage material rather than utilizing these important historic assets by preserving and optimizing them as a resource for the Indonesian people and future generations? It may be that the Indonesian Government still does not consider the significant contribution that archaeological sites and their associated cultural materials 
can provide in understanding the country's past when using and managing such resources in an ethical and sustainable manner.

Another possible hypothesis is the emphasis on the economic benefits from selling the salvaged artefacts. By considering the reason for the National Shipwreck Committee's conduct and the ramifications of commercial salvaging and the shared profit from selling the salvaged valuable material cargoes, the Indonesian government has argued that these activities represent national assets providing significance incomes and revenue for the country. In other words, it clearly defines the position of materially valuable cargoes as Indonesia's national treasure chest, and thus not as national cultural heritage resources.

Since 2012, the moratorium has stopped commercial survey and salvage activities, but the Indonesian Government has yet to formulate solutions to deal with issues related to its maritime culture resource management and the longterm strategies, i.e. conservation, curation, and display, for all salvaged artefacts. With this in mind, the author attempts to illustrate the disadvantages of the commercial salvage practices and the auction of salvaged artefacts. It sets out to assess the effect of illegal looting and commercial salvage projects on maritime cultural resources in Indonesia today. Subsequently, by identifying idiosyncrasies and providing some suggestions, where necessary, for improvement, it aims to contribute to a more ethical system of protection and the long-term management of the Indonesian maritime cultural resources, including its existing collections from salvaged shipwreck sites that are stored at the National Shipwreck Committee warehouse today.

\section{METHOD}

In order to answer the research questions, a proper method will be used as well as the relevant archaeological methods. Firstly, a literature review will be conducted to investigate the important aspects in this research. In general terms, this method is an appropriate technique and is used to describe a current body of research that aims to explaining and assisting professional practices, by identifying and developing new perspectives of research toward to interpreting existing literature (Fink, 2005). This review will cover the literature on ethical issues in maritime archaeology, including: commercial salvage activities and their impact on the maritime cultural resources; the study of artefacts as potential resources of material culture, and the practises of underwater cultural heritage management. They will be assessed with the aim of demonstrate the disadvantages resulting from commercial salvage activity of the shipwreck cargoes, especially those that occurred in Indonesian waters. The assessment aspects, which are related to the impact on the significance of these resources, consist of the aesthetic value, archaeological value, economic value, historical value, and research value.

Finding the way by reviewing the literatures of underwater cultural resources management is approached in with the aim to answer the main question in this research. Literature reviews themselves are important to support the identification of a research topic, question, or hypothesis that will have contributed to the research (Rowley and Slack, 2004, pp. 32). From the 
review of literatures, there are two broad approaches that can be used to investigate the focus on this research, they are:

1 . The reasons for studying of material culture;

2. The major impacts from ethical issues in maritime archaeology.

Related to the data that will be used in this research, there are five steps involvement of significance of a collection, such as:

1. Observation of the items;

2. Collecting the selected objects;

3. Researching their history and context;

4. Understanding the value and developing criteria;

5. Classification.

\section{DATA AND RESULTS}

As mentioned above, it has become clear that there are a lot of material cargoes or artefacts that were salvaged commercially - they are not utilized or studied properly. As a result, more than 190,000 artefacts, which were salvaged without archaeological standards and documentation, are stored at National Shipwreck Committee's warehouse under supervision of Indonesian Ministry of Marine and Fishery. More importantly, the commercial salvage process, in fact, induces the loss of the significance and context aspects that should be gained from historic shipwreck finds and their associations.

There is no need debating the ethics surrounding commercial salvage and treasure hunting activities. In another motive, the salvager has only pursued to recover or remove the underwater cultural heritage property for obtaining a reward from a court of competent jurisdiction (Brice, 1996, pp. 338). In fact, it always causes the impact that really harms the underwater cultural heritage property and the archaeologists. In this research, because of the lack of documentations and archaeological standards, this assessment will only focus on the aspects that have been lost from these 190,000 artefacts.

In the general terms of archaeology, material culture as well as the archaeological evidence is the most important aspect. Such as described in the literature review chapter, the artefacts within their environment or the place that they found contain much significant knowledge and information about human behaviour between the past and present (Binford, 1972). More specifically, context is one of very important aspect of archaeological research and interpretation. It assumes that archaeological evidence without context is similar to objects without valuable meaning.

This study will lay out for consideration the significance of contributions that can be gained by the study of the huge numbers of salvaged material artefacts and their associated cultures. This will represent a significant contribution in this context by means of exploring the advantages resulting from conducting the protection and preservation on the material cultures. Indeed, the contribution only can be understood by realizing four related aspects described below. The first aspect is the importance of material cultures. In general, the term material culture is used to describe the cultural products, including artefacts, objects and relics, made by a specific culture at a particular time 
(Prown, 1982, pp. 1-3). In the maritime or underwater archaeological context, this also includes shipbuilding and tools, which are associated with and represent the material evidence of societies in the past, such as natural materials, material production (pottery, ceramics, glass), and human remains (Viduka, 2012, pp. 6). Moreover, material culture is not only occurred in their context, but also conducts that context as the stage and sustain of human behaviour (McGuire, 1992).
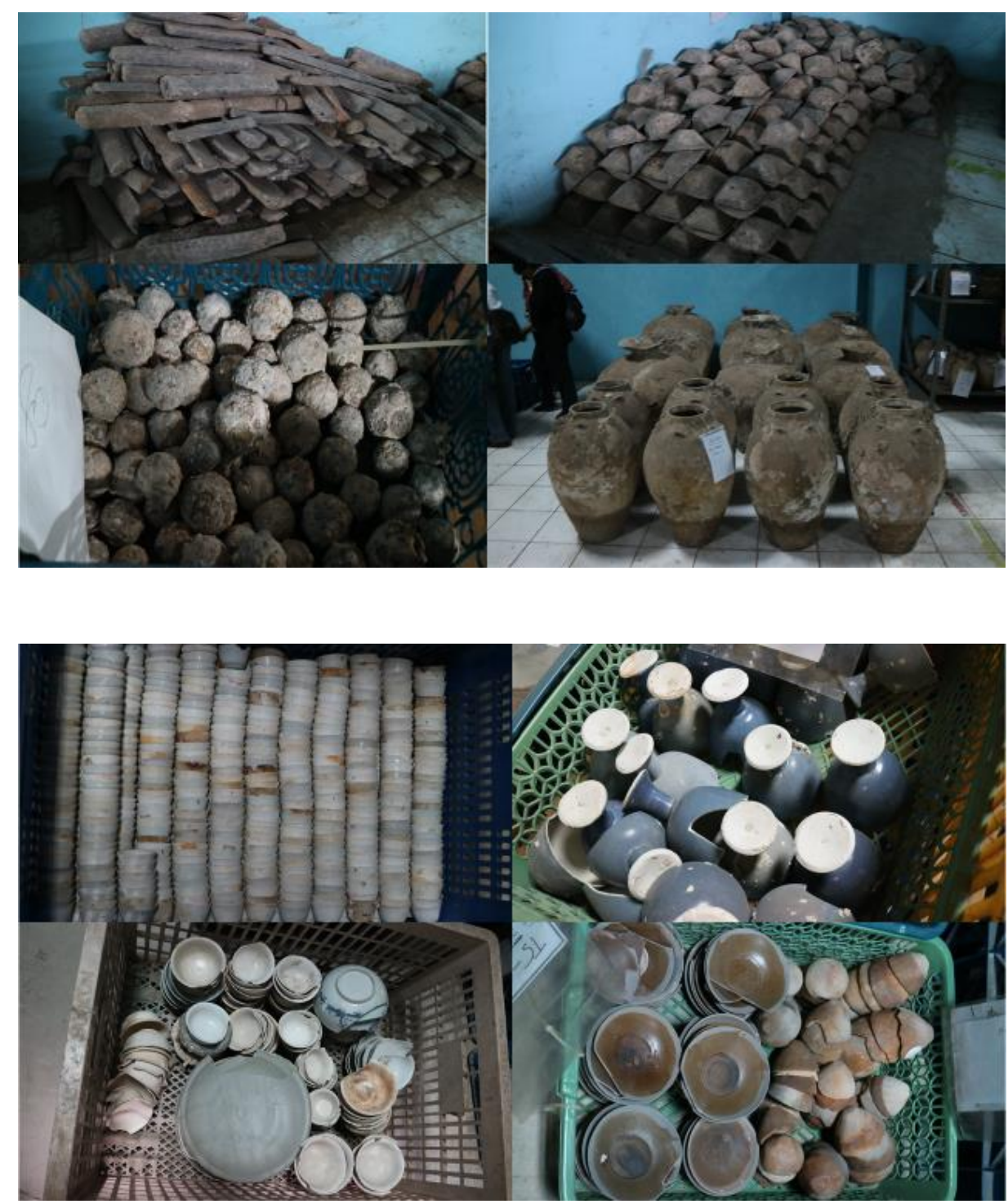

Figure 1. The Salvaged Material Cargoes from Historic Shipwreck Finds At The National Shipwreck Committee Warehouse

(Resource: Author). 
Table 1. The Commercial Salvage Databases Record

\begin{tabular}{|c|c|c|c|c|c|}
\hline No & Location & Companies & Years & $\begin{array}{l}\text { Numbers } \\
\text { of Material } \\
\text { Cargoes }\end{array}$ & Descriptions \\
\hline 1 & $\begin{array}{l}\text { Pulau Buaya, } \\
\text { Kepulauan } \\
\text { Riau }\end{array}$ & $\begin{array}{l}\text { PT. Muara } \\
\text { Wisesa } \\
\text { Samudera }\end{array}$ & 1990 & 16,031 & $\begin{array}{l}\text { Chinese Ceramics, Song } \\
\text { Dynasty }\end{array}$ \\
\hline 2 & $\begin{array}{l}\text { Batu Hitam, } \\
\text { Belitung (Tang } \\
\text { Cargo), Tuban }\end{array}$ & $\begin{array}{l}\text { PT. Sulung } \\
\text { Segara Jaya, } \\
\text { PT. TORR }\end{array}$ & 1999 & 10,757 & $\begin{array}{l}\text { Chinese Ceramics and } \\
\text { Metal from Tang, Song, } \\
\text { Yuan, Ming, and Qing } \\
\text { Dynasty; } \quad \text { Vietnam; } \\
\text { Thailand; } \\
\text { Southeast Asia }\end{array}$ \\
\hline 3 & Blanakan Sea & $\begin{array}{lr}\text { PT. } & \text { Lautan } \\
\text { Mas } & \text { Bakti } \\
\text { Persada } & \end{array}$ & 1999 & 13,590 & $\begin{array}{l}\text { Ceramics from Thailand, } \\
\text { Vietnam and China }\end{array}$ \\
\hline 4 & Karimata Strait & $\begin{array}{l}\text { PT. Tuban } \\
\text { Oceanic } \\
\text { Research and } \\
\text { Recovery (PT. } \\
\text { TORR) }\end{array}$ & 2002 & 31,029 & $\begin{array}{l}\text { Chinese Ceramics and } \\
\text { metal from Yuan Dynasty }\end{array}$ \\
\hline 5 & $\begin{array}{l}\text { North Java } \\
\text { Sea, Cirebon }\end{array}$ & $\begin{array}{l}\text { PT. Paradigma } \\
\text { Putra } \\
\text { Sejahtera } \\
\text { (PT.PPS) }\end{array}$ & 2005 & 271,834 & $\begin{array}{l}\text { Chinese Ceramics from } \\
\text { the five dynasties, } \\
\text { jewellery, Metal. }\end{array}$ \\
\hline 6 & $\begin{array}{l}\text { Karang } \\
\text { Heluputan } \\
\text { Sea, } \\
\text { Kepulauan } \\
\text { Riau }\end{array}$ & $\begin{array}{l}\text { PT. Adi } \\
\text { Kencana } \\
\text { Salvage }\end{array}$ & 2006 & 21,521 & $\begin{array}{l}\text { Chinese ceramics, } \\
\text { anchor, canon and metal } \\
\text { containers, from Ming and } \\
\text { Qing Dynasty }\end{array}$ \\
\hline 7 & $\begin{array}{l}\text { Teluk Sumpat } \\
\text { Sea, } \\
\text { Kepulauan } \\
\text { Riau }\end{array}$ & $\begin{array}{l}\text { PT. Adi } \\
\text { Kencana } \\
\text { Salvage }\end{array}$ & 2006 & 15,461 & $\begin{array}{l}\text { Chinese ceramics and } \\
\text { gem stones from Yuan } \\
\text { and Qing Dynasty }\end{array}$ \\
\hline 8 & $\begin{array}{l}\text { North Java } \\
\text { Sea, Jepara }\end{array}$ & $\begin{array}{l}\text { PT. Adi } \\
\text { Kencana } \\
\text { Salvage }\end{array}$ & 2008 & 14,814 & $\begin{array}{l}\text { Chinese Ceramics and } \\
\text { Chinese coins from Song- } \\
\text { Yuan Dynasty }\end{array}$ \\
\hline 9 & $\begin{array}{l}\text { North Java } \\
\text { Sea, } \\
\text { Karawang }\end{array}$ & $\begin{array}{l}\text { PT. Paradigma } \\
\text { Putra } \\
\text { Sejahtera } \\
\text { (PT.PPS) }\end{array}$ & 2008 & 6,442 & $\begin{array}{l}\text { Chinese Ceramics from } \\
\text { the Fives Dynasties }\end{array}$ \\
\hline 10 & $\begin{array}{l}\text { East Belitung } \\
\text { Sea }\end{array}$ & $\begin{array}{l}\text { PT. Paradigma } \\
\text { Putra } \\
\text { Sejahtera } \\
\text { (PT.PPS) }\end{array}$ & 2009 & 37,680 & $\begin{array}{l}\text { Coins, Canon, and } \\
\text { Ceramics from XVII CE }\end{array}$ \\
\hline 11 & $\begin{array}{l}\text { Ujung } \\
\text { Pamanukan } \\
\text { Sea }\end{array}$ & $\begin{array}{l}\text { PT. } \\
\text { Comexindo } \\
\text { Usaha Mandiri } \\
\text { (PT.CUM) }\end{array}$ & $\begin{array}{c}4 / 1 / 2010 \\
\text { (Unfinished) }\end{array}$ & 18,469 & $\begin{array}{l}\text { Chinese Ceramics from } \\
\text { Ming Dynasty }\end{array}$ \\
\hline
\end{tabular}

Then, Julian Thomas discusses how material culture can provide cognitive aspects and substantial human progress (Thomas, 1996). Furthermore, material manifestations can represent the internalized norms and values of a culture by looking their patterns and templates (Childe, 1936; 1942). Material cultures are also considered as an illustration of their meanings to be structured much like a text (Hodder, 1992). More importantly, material culture is very resistant to analyse and interpret as the primary data for researchers, especially for archaeologists (Guarnello, 2005, pp. 19-27). 
The second aspect is treasure hunting and its impact on underwater cultural heritage or cultural resources. This issue is begun from the destruction of shipwrecks and many thousands of other underwater sites due to the exploration by salvage companies which were occurred in the past. The recovery of material cargoes from shipwrecks on the sea floor is an activity which has occurred for centuries. In the middle of the 20th century, around 1940-1950, many materials are salvaged in variety of sea depths and by different nations around the world, such as some regions in the United States, European countries, Mediterranean regions, and many countries in Asia.

For instance, a boom of treasure hunting activity occurred in Florida (USA) after the discovery of the 1715 plate fleet off Vero Beach (Throckmorton 1990, pp. 8). Another salvage case occurred in the Mediterranean where there is a large number of Roman shipwrecks in different places such as Grand Conglouē, Cape Dramont, and Ĭle du Levant in France; Mahdia of Tunisia, and Albenga in Italy (Du Plat Taylor, 1965). Salvage was undertaken by, small groups, or even by big companies before and as a result the development of SCUBA gears and diving equipment (Bas,s 1966, pp. 1-22; 1983, pp. 389). During the salvage, divers removed artefacts from the seabed without applying any archaeological methods; meanwhile the archaeologists just had to wait on the deck or surface.

The third aspect is the archaeological action of countering the salvage issue by conducting and developing the appropriate underwater and maritime archaeology practice, theory, and methods. The beginning of the shipwreck and nautical archaeology era was pioneered by SCUBA divers and John Goggin, who began the task of investigating shipwrecks (Frost, 1963; Goggin, 1959; 1960). In the 1960s, the number of nautical archaeology projects exploded. The discovery of a Viking ship in Denmark by divers and its subsequent excavation by archaeologists using a cofferdam (CrumlinPedersen and Olsen, 2002), the discovery of a Bronze Age shipwreck which found at Cape Gelidonya, Turkey, which was the first excavation done on the seabed (Bass, 1967), along with the excavation of the warship Vasa in the waters off Stockholm, Sweden (Cederlund, 2006) were noted as significant results from this beginning of the global spread of shipwreck and underwater excavations. After these discoveries, other underwater shipwreck excavation projects followed around the world including the 16th-century Basque whaler at Red Bay in Canada (Grenier, Bernier and Stevens, 2007); the 1554 Spanish wreck at Padre Island in Texas (Arnold and Weddle, 1978); the 17th-century Portuguese shipwreck in Kenya (Piercy, 2005); the 14thcentury shipwreck in Korea (Keith, 1980); Spanish fleet wrecks in Ireland (Martin, 1975); a classical Greek in the Messina Strait (Eiseman and Ridgeway, 1987): and the Dutch East India Company ships in Australia (Green, 1977).

The fourth aspect relates to the utilization of artefacts from shipwreck salvage projects. The main purpose of salvaged material cargoes is to seek profit by selling them to collectors. Contrary to archaeology, salvagers do not undertake any further research, preservation, conservation, and publication of the studies of the ships and their associated artifacts (McManamon, 2005; Flatman, 2007; Van Tilburg \& Staniforth, 2012). Archaeological projects keep all of the raised material cargoes-they are preserved, stored, and displayed at museums in order to keep them save 
for future generations and public consumption (Bass, 2011, pp. 16). Museums with complete shipwreck collections are, for example, the Vasa Museum in Stockholm, Sweden, the Bodrum Museum of Underwater Archaeology in Turkey (Bass, 2011), and the Mary Rose Museum in Portsmouth, UK. Their exhibitions attracted many visitors and they successfully generated significant income for their respective country. Therefore, archaeologists assist with national incomes by using proper strategies to utilize and manage the material cargoes.

Shipwrecks and their cargoes, in fact, are valuable sources of knowledge and information. In particular, shipwreck cargoes themselves may provide conflicts related to their commercial or economic value, which arise from events including jurisdiction, access, preservation, recovery, proprietorship, sale and display of materials (Smith, 2003, pp. 25). Therefore, this research illustrates the significance loss of valuables of potential maritime cultural resources in Indonesia.

\section{DISCUSSION}

In this research, those artefacts originally in context, have been salvaged or removed from their contexts in the most unethical way and without the use of archaeological methodology. As a result, these salvaged material cargoes from 10 sites are considered to have no valuable meanings. In fact, there are five essential values that have been lost from the commercial salvages that have been done. Those five consist of the aesthetic, archaeological, economic, historical, and research values. Moreover, those aspects are assumed as having been disregarded from the concern of the related Indonesian Government agency.

The aesthetic value aspect is placed as the first major significant loss in this assessment. The salvaged shipwreck and its material cargoes from those 10 sites are considered as the impressive potential Chinese shipwrecks from XI - XIII centuries. Moreover, those huge numbers of salvaged material cargoes as well as the underwater historic remains, also show the variety of underwater archaeological remains which represented the valuable evidences of trading between Indonesia and China. In more detail, these artefacts are very suitable to be displayed for exhibition purposes in museum as well as a part of publication, education, and promotion to public.

For the archaeological value, all of these salvaged artefacts are considered as the incredible discovery. Those major numbers of material cargoes may reveal interesting and significant information related to the life on board, the social organization on ship, and the division of space on the ship. From these valuable resources may, in turn, strength our knowledge about the process and pattern of Chinese cultural resources trading during the XI - XIII centuries. It also contains the other important knowledge and information of the artefacts itself, including the typology of Chinese artefacts that comprise of ceramics, coins, metals, silvers, and other related archaeological remains.

In perspective of research value, for researchers, especially archaeologists and anthropologists, material cultures are the primary data in their research projects. However, there are two conditions that should be of concern to researchers. Firstly, the principle of context is the major concern for the study of 
artefacts. Without context or the association between the archaeological objects and their environments, archaeologists will have lost the detail necessary for knowledge and information gathering during their interpretation phase. Secondly, the other condition relates to the unethical system and techniques of recovering the artefacts. In this context, the material culture of historic shipwrecks from underwater sites or the seabed is considered. In maritime archaeology research projects, underwater excavation or recovery the removal of artefacts from the in situ context is generally placed as the very last option to be undertaken. However, if forced to do, the underwater excavation should conduct the archaeological standard and procedure to be accomplished. This becomes important because of the commercial salvage technique that is quite often destructive and really harmful, both for the shipwreck as well as for the natural environment. The worst thing is the commercial salvage undertaken without inappropriate archaeological documentation of the site, while the salvagers publish dramatic documentation in order to attract the public and collector attention to gain support for their existence as the saviour of underwater treasure.

Subsequently, the historical aspect is assumed as the other vital element that also lost from the essence of Indonesian maritime cultural resources. The evidence of huge valuable underwater artefacts is an important tile in the mosaic of the Chinese Silk Road history in the past. Not only the China history, it also strengthens the proof of Indonesian maritime glory in the past. Furthermore, the reasons for which these artefacts were traded, as well as the popular commodities during IX - XIII Centuries, are possible to encourage the interests and awareness both for researchers and the public.

Lastly, the economic aspect is another loss from Indonesian maritime cultural resource essence. In this context, the economic value has different meaning in comparison with the economics from the salvager or treasure hunter perspective. The consideration of economic value from maritime archaeology perspective is the potentiality of maritime cultural asset or property of a nation, in this case, Indonesia. Indeed, Indonesia has lost the economic profit from the shipwreck cargoes that have already been salvaged and sold at the auction house. Indonesia also missed out on the benefits from the potential of tourism to the sites where visitors can see the artefacts. Furthermore, the financial advantages that could be gained from the museum exhibition, temporary or permanently, are also considered as part of the disadvantage to Indonesian economy.

\section{CONCLUSION}

As described by Keith Muckelroy, material cultures are the all-important aspects of seafaring including ships, boats, and their material cargoes, passengers; and the economic systems on ship between the crew and passengers (Muckelroy, 1978, pp. 6). Therefore, material cargoes from the historic shipwreck finds are assumed to be strong evidence for conducting the deep water investigation as part of maritime archaeology research, especially, the underwater archaeological shipwreck. However, all 
archaeological research should consider about the importance of association between the material cultures and its environment known as the context. In more detailed maritime archaeology terms, material cultures from maritime and underwater contexts are associated with some important aspects such as the relationship between the material cargoes and other objects and the reasons for packaging and transporting the objects (Staniforth, 1996).

In order to realize this consideration, all of the related aspects need to work in harmony and take a quick action to encourage the central Government of Indonesia. Firstly, they need to define the processes relating to the discovery of underwater cultural heritage resources and register them with UNESCO as the Indonesian cultural heritage assets. Furthermore, they should construct shortterm and long-term plans that not only focus on the conservation and protection of the available underwater cultural heritage resources, but also on discovering other potential resources around Indonesian's territorial waters.

For the further recommendation, Indonesian Government should have more concerning the importance of their maritime cultural resources evidences; and to determine the salvaged artefacts status as the Indonesian maritime cultural resources and assets that need to be utilized more properly. Subsequently, the establishment of underwater cultural heritage and Maritime Archaeology discipline program in Indonesia should be developed in full career. This development is really important to create the best qualified scholar of maritime archaeology. However, Indonesia should prepare some aspects before establishing this program as mentioned above. Indeed, Indonesia already has a large number of underwater cultural resources from the salvaged material cargoes that are stored at the National Shipwreck Committee warehouse. Meanwhile, the appropriate facilities, the available spaces, and the supporting archaeological equipment are assumed as the external aspects that need to be fulfilled to strengthen the establishment of this program.

Increasing the museum performance to utilize and explore the potential values of the current salvaged artefacts at the National Shipwreck Committee warehouse is considered to be the next recommendation to improve the maritime cultural resource management in Indonesia. Although, the Government should determine the capable institution, in this context, the museum is the appropriate institution to undertake those archaeological procedures relating to those resources including conserving, desalinating, documentation (photographing and recording), labelling, and registering of the artefacts. Moreover, the Government could develop a collaborative unit between the National Shipwreck Committee, and the Cultural Heritage Protection Unit, which facilitated by the Museum to strengthen communication, stresses the seriousness of, and promote more concern about the protection, preservation, conservation, and utilization of maritime cultural resources in Indonesia, especially those huge number of salvaged material cargoes that are stored at the National Shipwreck Committee. 


\section{REFERENCES}

Adams, J.L. (2010). New Directions in International Heritage Management Research. (Unpublished $\mathrm{PhD}$ Thesis Anthropology). University of Minnesota, Minnesota.

Arnold, J.B. and S.R. Weddle. (1978). The Nautical Archaeology of Padre Island: The Spanish Shipwrecks of 1554. New York: Academic Press.

Bass, G.F. (2011). The Development of Maritime Heritage. In A. Catsambis, B. Ford, and D.L. Hamilton (eds), The Oxford Handbook of Maritime Archaeology, pp. 3-24. Oxford: Oxford University Press.

Bass, G.F. (1983). Shipwrecks and Treasure Hunter. Journal of Field Archaeology, $10,389$.

Bass, G.F. (1966). Archaeology Underwater. London: Thames \& Hudson; New York: Frederick A. Praeger.

Binford, L.R. (1972). An Archaeological Perspective. New York, Seminar Press.

Cederlund, C.O. and F. Hocker. (2006). Vasa 1: The Archaeology of a Swedish Warship of 1628. Stockholm.

Childe, V.G. (1936). Man Makes Himself. Watts: London.

Crumlin-Pedersen, O. and O. Olsen (eds.). (2002). The Skuldelev Ships 1: Ships and Boats of the North, vol. 4.1. Roskilde: Viking Ship Museum.

Du Plat Taylor, Joan, (ed.). (1965). Marine Archaeology. London: Hutchinson.

Edwards, H. (2000). Treasures of the Deep. The Extraordinary Life and Times of Captain Mike Hatcher. Pymble (New South Wales): HarperCollins.

Eiseman, J.C. and Ridgway S.B. (1987). The Porticello Shipwreck: A Mediterranean Merchant Vessel of 415-385 B.C. Ed Rachel Series in Nautical Archaeology. College Station: Texas A\&M University Press.

Fink, Arlene. (2005). Conducting Research Literature Reviews: From the Internet to Paper, 2nd ed. Thousand Oaks, CA: SAGE Publications.

Flatman, J. (2007). The Origins and Ethics of Maritime Archaeology Part 1. Public Archaeology, 6(2), 77-97.

Flatman, J. (2007). The Origins and Ethics of Maritime Archaeology Part 2. Public Archaeology, 6(3), 141-154. 
Flecker, M. (2012). The Ethics, Politics, and Realities of Maritime Archaeology in Southeast Asia. The International Journal of Nautical Archaeology, (31.1), 1224.

Flecker, M. (2002). The Archaeological Excavation of the 10th Century Intan Shipwreck. BAR International Series 1047. Oxford: Archaeopress.

Frost, H. (1963). Under the Mediterranean: Marine Antiquities. Englewood Cliffs, NJ: Prentice-Hall.

Goggin, J.M. (1959-1960). Underwater Archaeology: Its Nature and Limitations. American Antiquity, 25, 348-354.

Grenier, R. B. and W. Stevens, (eds.). (2007). The Underwater Archaeology of Red Bay: Basque Shipbuilding and Whaling in the 16th Century, 5 vols. Ottawa: Canada.

Green, J.N. (1977). The Loss of the Verenigde Oostindische Compagnie jacht Vergulde Draeck, Western Australia 1656. Oxford: British Archaeological Reports Supplementary Series 36(i).

Guarinello, N.L. (2005). Archaeology and the Meanings of Material Culture. In P.P. A. Funari, A. Zarankin, \& E Stovel (eds). Global Archaeological Theory: Contextual Voices and Contemporary Thoughts, (1):19-27. New York: Kluwer Academic/Plenum Publishers.

Hodder, I. (1992). Theory and Practice in Archaeology. London: Routledge.

Johnston, P.F. (1997). “Nanking Cargo Wreck." In Encyclopaedia of Underwater and Maritime Archaeology, J. P. Delgado (ed.), pp.287-88. London: British Museum Press.

Keith, D.H. (1980). A Fourteenth-Century Shipwreck at Sinan-gun. Archaeology, 33(2), 33-43.

Lenihan, D.J. (1983). Rethinking Shipwreck Archaeology: A History of Ideas and Considerations for New Directions. In R. Gould (ed.), Shipwreck Anthropology, pp. 37-64. Albuquerque: University of New Mexico Press.

Maarleveld, T.J. (2011). Ethics, Underwater Cultural Heritage, and International Law. In A. Catsambis, B. Ford; D. L Hamilton the Oxford Handbook of Maritime Archaeology, pp. 917-941. Oxford: Oxford University Press.

Martin, C. (1975). Full Fathom Five: Wrecks of the Spanish Armada. New York: Viking. 
McManamon, F.P. (2005). The Public Interpretation of America's Archaeological Heritage. SAA Archaeological Record, 22-23.

Muckelroy, K. (1978). Maritime Archaeology. Cambridge University Press, Cambridge. Piercy, R. 2005 The Tragedy of the Santo Antonio de Tanna: Mombasa, Kenya. In G. F. Bass (ed.), Beneath the Seven Seas, pp. 172-179. London: Thames \& Hudson.

Prown, J.D. (1982). Mind in Matter: An Introduction to Material Culture Theory and Method. Winterthur Portfolio Spring 17(1): 1-19.

Rowley, J., \& Slack, F. (2004). Conducting a literature review. Management research news, 27(6), 31-39.

Sheaf, C. and R. Kilburn. (1988). The Hatcher Porcelain Cargoes: The Complete Record. Oxford: Phaidon.

Smith, D.H. and C.D. Alastair. (2003). The Management of the Underwater Cultural Heritage. Journal of Cultural Heritage, (4), 25-33.

Staniforth, M. (1996). Tracing Artefact Trajectories following Chinese Export Porcelain. Bulletin of the Australian Institute for Maritime Archaeology), 20(1), 13-18.

Thomas, J. (1996). Time, Culture, and Identity: An Interpretive Archaeology. London: Routledge.

Throckmorton, P. (1990). The World's Worst Investment: The Economics of Treasure Hunting with Real Life Comparisons. Florida: Nova University.

Van Tilburg, H.K \& M. Staniforth, (2012). Archaeological Publication. In Training Manual: for the UNESCO Foundation Course on the Protection and Management of Underwater Cultural Heritage in Asia and the Pacific. Published by UNESCO Bangkok, Thailand.

Viduka, J.A. (2012). Material Culture Analysis. Training Manual for the UNESCO Foundation Course on the Protection and Management of Underwater Cultural Heritage in Asia and the Pacific. Thailand: UNESCO Bangkok. 